\title{
Potential Contribution of Tamale International Airport to the Development of Northern Ghana
}

\author{
Abdul-Wadood Moomen ${ }^{1}$
}

(C) Uganda Martyrs University

\begin{abstract}
Empirical analysis of the socio-economic benefits and challenges of air transport in Ghana has not received much attention. This is in spite of the fact that policy makers and aviation operators need such analysis to implement regional development initiatives. The general objective of this study, therefore, is to examine the economic effects and challenges of air transport in Ghana, with the feasibility of the proposed development of the Tamale Airport to International status as the prime focus. Information is derived from the literature, work place counts and resource persons. A major finding of the study is that air transport contributes immensely to economic growth and poverty alleviation--through direct and indirect employment and through tax revenue generation (from its catalytic impact on other industries like tourism). It is argued that developing Tamale Airport must be considered as a complete business environment and a leading West African main Airport, by virtue of its strategic location. This is crucial to the growth prospects of the three regions of Northern Ghana expressed in the establishment of the Savannah Accelerated Development Authority (SADA).
\end{abstract}

Keywords $\cdot$ Aviation $\cdot$ Economic growth and development $\cdot$ Ghana

\section{Introduction}

Air transport has a broad impact on a nation's economy by simulating it through direct, indirect and induced ways. Apart from quantifiable economic benefits, air transport also generates tangible (spin-off) benefits. These include reducing the loss to trade and movement, attracting new businesses to locations with good air service links and support for the development of new technology and distribution processes and goods.

Developed nations have indentified air transport as a vital economic powerhouse. The USA developed a progressive aviation policy aimed at unmasking its general potentials. At the forefront of the Aerospace industry, the USA continues research and development of the industry to broaden its economies of scale.

\footnotetext{
${ }^{1}$ Curtin University of Technology, Australia. E-mail: wadood35@yahoo.com
} 
Countries like Kenya, Gambia, Thailand and Indonesia have realized overall national growth through air transport base tourism. Today, air transport industry is the bedrock of Ethiopia's economic strength. Seychelles' tourism increased after the opening of its international Airport in 1971. Today, through aviation, tourism provides over 50\% of GDP to Seychelles, while accounting for more than $20 \%$ of all employment and $70 \%$ of foreign exchange.

In the light of these growth prospects of air transport sector, the Economic Community of West African States (ECOWAS) set in motion its aerospace initiative by establishing an ECOWAS airline. This move aims at tapping the regions potential, while fostering regional integration. It is quite regrettable that Ghana's efforts at embracing the enormous air transport industry's self spoken benefits are still panting for a collaborative attention. Looking at the wide ranging sectors of the economy of Ghana, there is no contradiction that the totality of the transportation sector is one of most vital but least developed and impoverished this country has ever witnessed, particularly within the northern regions.

In the latter part of 1970, during the era of Nigeria's oil boom, the federal government embarked upon substantial development of her transport infrastructure to meet the growing number of the populace, and to boost up in-flow of foreign Direct Investment (FDI). As a result, the state saw the provision of commuter air transportation that shuttled between the hinterlands and port regions. Ghana has also discovered oil, which calls for an urgent action like that of Nigeria to support the transport industry in order to be able to rise up to the transportation needs of an oil producing economy. Multiplier effects of dosages of money brought into the local economies of the three regions of the north by tourist spending contribute generally, to wealth creation and optimum socio- economic growth. This will fit into national goal of achieving sustainable and equitable economic growth, accelerated growth and accelerated poverty reduction.

The aim of this paper is to raise the level of awareness of the developmental needs of the aviation sector especially, in the deprived and destitute regions of the country, and make attempts to find solutions to the myriad of problems facing the sector, as well as suggest ways the local indigenes can benefit from the sector. The air transport industry has great potentials such as job creation, improve on the quality of education and educational infrastructure and generally improve the living standards of the people. These potentials serve not only the enhancement of material well being, but also generate individual and societal self- esteem.

The next section discusses the development of air transport industry in Ghana; from the colonial era to date. Section 3 evaluates the economic benefits of the air transport industry. These benefits are classified under direct, indirect, induced and catalytic impacts. Section 4 explains the relationship between the air transport development and the economy of three regions of northern Ghana. This section constitutes the basis of this study. Finally section 5 closes the discussions by summarizing the major finding $\mathrm{s}$ of this paper coupled with pragmatic suggestions and contribution. This paper will have an impetus on the poverty alleviation strategies of Ghana.

\section{Development of Air Transport in Ghana}

Air transport in Ghana dates back to October, 1918. Firstly, Vickers Aviation Limited requested Sir Frederick Gordon Guggisberg, then governor of Gold-Coast, to permit the deployment of their aircraft in the colony. In 1919, Swinton Limited (Air transport 
operators), London, also presented an application to initiate negotiation with the colonial government on aerial transportation. Consequently, the governor summoned a four member commission to submit a feasibility report on "Air Transportation in the Gold Coast".

Upon a favourable report from the commission, the British government opened the way for survey work on the establishment of aerodromes in the colony. The following sites and locations were recommended after the survey work: Accra-Polo Grounds (Now Nkrumah Museum), Kumasi-old Polo Grounds, and in Tamale-the Constabulary Parade Grounds. Thus, airfields were constructed to serve the air transport needs of the country.

After an air tour round Africa in a flying boat by Sir Alan Cobhan of Alan Cobhan Aviation Company of UK, a report was presented to the Governor, Captain Rattray, in the following words:'I trust that the enthusiasm and keenness everyone displayed will not be permitted to die away entirely, but all those good works on the part of those who helped and largely contributed to make this flight a success, will soon bear fruits and bring appreciably nearer the day when the Gold Coast can boast of its own air service"(Dwemoh and Associates, 2007). The first aircraft ever to visit the country landed on 15th April, 1928, piloted by Sir Alan Cobhan in a flying boat called "Singapore"

The Kotoka International Airport (KIA) was built in the pre-war years on a small scale to serve as an instrument of expeditious transportation of mails, goods and persons and for economic development in British West Africa (Dwemoh and associates, 2007 p.19).The KIA received a huge facial uplift after the World War 2, when its location was recognized as advantageous. Then Accra Airport, the KIA was identified as a strategic staging-post for the re-enforcement of Allied Forces in North Africa and the Middle East.

Further development in aviation then took the form of providing and extending facilities including: extension of existing runway, building of control Tower, Hangars, workshop and other technical buildings. This intended to equip and convert then Accra Airport (KIA) into a military Aerodrome to meet the wars' vital necessities for victory. The colonial government returned the administration of the Air service to civil use after the Second World War. This move saw the recruitment of demobilized Ghanaian soldiers into various sections of the air transport service. After the enactment of the Civil Aviation Act in 1958, the power to regulate civil aviation and air navigation, and develop air transport generally in the new Ghana, was vested in the new Ghanaian government.

However, the republican government of Ghana apprehended full control of aviation and air transport activities in 1960.By 1962, about 800 Ghanaian youth were employed at the air transport service directly. This number comprised of skilled, semi-skilled, and unskilled labour serving in various capacities such as air traffic control, clerks, clearance, security, cleaner and ramp men.

Currently, apart from KIA, Takoradi, Kumasi, Sunyani, and Tamale airports handle passengers on daily flight schedule basis. Precisely 344 Ghanaians are serving directly in various capacities under Ghana Civil Aviation Authority (GCAA), 589 in Ghana Airports Company Limited (GACL) making a total of 933 of indigenous labour force. Airline companies (domestic and international) have also engaged a good number of Ghanaians.

PNDC law151, 1986, moved the Civil Aviation Department (CAD) to Civil Aviation Authority (CAA) in order to make it more efficient and self-reliant and financially independent. An Act of parliament further decoupled the functional responsibility of the air transport sector in 2006. Hence, entities in-charge of Ghana's air transport services of late are the GCAA and GACL, to make way for optimum output. The core responsibility 
of GCAA, as per the act, is to ensure safety and reliable air navigation and general aviation development in Ghana. Registered in 2006, the Act vests the responsibility for planning, developing, managing and maintaining all airports and aerodromes in Ghana upon GACL.

Therefore, in 2011, Ghana's aviation market grew by $15 \%$ (my peace fm online.com), and the same growth rate figure is expected for the industry in 2012.It is significant to note that, like globalization, the entire fashionable world of business is absolutely tied to the apron string of logistics and transportation conceptualization in this $21^{\text {st }}$ century (Joe Effah, Graphic.com.gh).

On operational issues, Ghana's airline industry is growing, though small, requiring the operation of an additional international airport to accommodate more airlines and freight. At the time of this research, Ghana has 28 international airlines and 4 domestic airlines.

Majority of African countries depend on few African based and foreign airlines to provide air services. According to Economic Commission of Africa's (ECA, 2003) study, around $75 \%$ of air traffic to and from Africa is carried by foreign airlines. Schlumberger (2007, p.38) classifies Ghana under a third category of African countries that have private airline operators.

\section{Impacts of Air Transport Industry}

The aviation industry has a buoyant and generic economic impact, both through its own activities, and as an enabler of other industries. Under the industry's own activities, the impact could be direct or indirect. The aviation transports close to 2 billion passengers worldwide annually, and $40 \%$ of interregional exports of goods. The industry generates US\$29billion, equivalent to 8\% of world GDP (Oxford Economic Forecast, OEF, 2004).

\section{Direct Economic Benefits}

A major direct benefit of the air transport industry is employment and wealth creation. The industry contributes significantly to improving living standards and alleviating poverty. The industry deploys skilled, semi-skilled and unskilled labour to contribute in diverse ways for expansion. Personnel such as clerks, dispatchers, immigration and custom officials, security, flight crew, airline ticketing agents and many more are brought on board. About 4.3million people worldwide are employed by the airlines and airports (OEF, 2004), contributing around US\$275billion of GDP to the global economy. About 2.1 million people work for airlines and handling agents worldwide. Examples include flight crew and maintenance crew. About 330,000 people work directly for airport operators. Approximately, 1.9million work on-site at airport in retail outlet, and restaurants (OEF, 2004).

\section{Indirect Economic Benefits}

The air transport industry creates about 5.8million indirect jobs through purchases of goods and services from companies of its supply chain. The supply chain comprises of, but not limited to, aviation fuel suppliers, construction companies that build additional facilities, the manufacture of goods sold in airport retail outlets, call centres, and taxi services at the airport.

\section{Induced Benefits}

The air transport industry induces employment and wealth creation in association with direct wages and salaries due workers. Spending by those directly and indirectly employed 
in the aviation sector support jobs in areas such as unit vendors, and companies producing consumer goods (Banks, Insurance Companies, Restaurants). About 2.7million induced jobs are created globally through spending by industry employees (OEF, 2005). The air transport industry is one of the most efficient sectors measured in terms of GDP per worker. It is estimated that individual employees of the industry contribute about US\$ 65,000 per year to global economy (OEF, 2005).

\section{Multiplier Effects of the Industry}

The air transport most importantly economic contribution is, through its impact on the performance of other industries and as a significant facilitator of their growth. Industries that stand a tall chance of benefiting from air transport external economies of scale include: trade, tourism, location of investments, labour supply, and market efficiency and levy taxation.

Air transport plays a pivotal role to world trade. It facilitates countries participation in global market (Globalization) by enhancing access to main markets. However, Mergesa (2007) has observed that African countries are effectively ruled-out of trade in international aviation service, mainly because, factor endowment (capital and skilled labour) and ability of airlines to exploit economies of scale make African countries comparatively disadvantaged. Additionally, air transport encourages countries to specialize in activities they have a comparative advantage, and to trade with countries producing other goods. For example, in Kenya, exports by air of agricultural products such as fresh vegetables and cut flowers largely to Europe already constitute one of the country's largest industries and the second biggest earner of foreign exchange. It is also very significant to mention that the world is effectively shrinking in terms of distance that can be covered in a given time period due to faster and more efficient transport; air transport couple with development in other technologies. Air transport contributes to improved living standards for many developing nations by expanding opportunities to join the global economy.

The development in technology and transport infrastructure such as jumbo jets, low-cost airlines, and more accessible airports have made many types of tourism more affordable. In turn, tourism directly supports jobs in airline and airport operations. Also, spending of visitors arriving by air creates a substantial number of jobs in the tourism industry. The tourism industry worldwide directly employs 72 million people accounting for $3.8 \%$ world GDP, (OEF, 2005). Tourism depends on transportation to bring visitors; hence, air transport stimulates tourism, while the transport industry depends on tourism to generate demand for its services. A $20 \%$ of 600 million annual international tourist arrivals worldwide are by air transport. The economic significance of tourism has therefore increased dramatically in recent years.

Global tourism expenditure is estimated to be nearly US\$ 3billion (World Travel \& Tourism Council, WTTC, 2005). By 2014, the WTTC expects the tourism industry to employ more than 84 million people globally. The industry comprises of obvious sectors such as hotels, restaurants, bars, recreational activities. The obscuring benefits of tourism comprises of retailing in many heavily visited areas. Other benefits include diversification of economic base at national and local levels, increases public revenue through taxes on individuals and corporate earnings, leads to development of allied industries such as textiles, jewellery, pottery, food and beverages with substantial direct and indirect employment opportunities. Around $40 \%$ of international tourists now travel by air from 
35\% in 1990 (International Civil Aviation Organization, ICAO, 2004). Ghana is the leading tourist destination in West Africa. It is the fourth largest foreign income earner after cocoa, gold and remittances (Ghana Statistical Survey, GSS, 2010).

Viable air transport links are some of the key considerations that influence where international companies choose to invest. According to a survey, 56\% of companies consider international transport link to be crucial factor for locating businesses in Europe (Healey and Baker, 2003). Another survey found out that $18 \%$ of businesses past investment decisions were directly affected by the absence of good air transport links, especially in high-tech sectors. Around $28 \%$ of companies believe that innovations and investment in research and development would be fairly badly affected if air transport services were constrained (OEF, 2005).

According to a survey of financial and business service companies, almost $17 \%$ of firms consider air service to be critical for business travel; 50\% respondent consider air services to be critical for travel by their client to meet with them, and while new technology such as video conferencing can be useful. Companies in the financial and business service sector still consider flying for face to face meeting to be essential for winning new business and developing clients' relationships (OEF, 2002). Economic benefits are maximized in a region if it can specialize in the production of those commodities and trade it has comparative advantage. Trading will result in specialization in the under developed regions, to be accompanied by economies of scale and higher productivity. Increasing per capital income will imply higher savings and investments, and the process of development set in motion (Hilhorst, 1967).

Air transport improves the labour market by making it easier for companies to attract high quality employees from around the globe. Similarly high quality employees from around the country may find it easier commuting by air on weekly basis in two locations (i.e. Headquarters and Regional Location). Skilled workers and professionals, who previously could reject postings and transfers to the North of Ghana, now accept it in a good fate. Overall, improved access to a wider pool of appropriately skilled labour will improve productivity leading ultimately to higher employment in the local economy.

The air transport industry pays substantial taxes to local, provincial and national authorities around the world via passenger duties, domestic Value Added Tax (VAT), customs or immigration levies. For instance, air transport is the only transport mode that pays both user charges and taxes. Airport companies also transfer their surplus revenues to the central government as royalties and dividends.

\section{Tamale Airport vis-à-vis the Northern Poverty Alleviation}

The development of Tamale airport in relation to poverty alleviation in the three poorest regions of Northern Ghana (Upper East, Upper West, and Northern Regions) takes the form of "trickle-down effect and polarization" involving the cyclic movement of capital, labour and commodities. A growth pole, according to Boudeville (1996), is a set of expanding industries located in an urban area and inducing further development of economic activity throughout its zone of influence (peripheries). The growth pole in this context is Tamale, while the peripheries are Wa and Bolga in the Upper West and Upper East Regions respectively. This is more vividly explained by Walter Christaller's central place theory. The theory posits that the size and distribution of market and service centres varies according to relative size (population and purchasing power). 
In Christaller's transport principle model, the goal is to minimize the length of roads needed to join all adjacent pairs of central places. Christaller's central place theory is a theoretical account of the size and distribution of settlements within an urban system in which marketing (economic activities), is the predominant urban function facilitated by transportation. A hierarchy of central places can be established by classifying each central place according to the highest order good or services it supplies. At the apex of the hierarchy there will be a largest central place in the region (capital city or most industrial city) with its zone of influence large enough to support more than one outlet for all the orders of goods and services (Yaro, 2009). In this discourse, Tamale (the only Metropolis in the North) becomes the highest order central place providing Wa (Upper West Regional Capital) and Bolgatanga (Upper East Regional Capital) with goods and air transport catalytic services. Wa and Bolga in turn supply other districts and rural areas constituting the next order.

Bertel Ohlin, regional development expert, assumes that in the early stages of regional development, when the transport and communications networks between the developing and the developed regions are weak, trade between these regions will be dictated by the principle of comparative advantage. The productive capacities of all regions are mobilized by linking them in both structural and an organizational sense to the mainstream of the economy. For instance, Upper East Region could specialize in tomatoes and beef production and processing for export. Crocodile pond at Paga, and similar attractions to be developed to add up to the specialization of the region. The hippopotamus sanctuary at Wuchau in the Upper West Region, Salaga slave camp, Gambaga escarpment and witch camp, Mole national park, the mystic stone and mosque, all in the Northern Region are aspect of specialized areas that can contribute immensely to the local economies, when developed to WTTC set standards.

Developing Tamale airport to an International standard has the potential of "cumulative circular causal effect" (Myrdal, 1957). Trickle down and cumulative effects and experiences shall be the economic deriving trajectory for the Upper East, Upper West, and Northern and by extension North-Eastern Brong-Ahafo and Volta regions. The opening up of the Tamale Airport shall lead to expansion of employment directly by the industry, indirectly by industry's suppliers, and other related industries. Perhaps, the activities of the industry at the airport could lead to reduced seasonality as surplus labour, during offfarming seasons; seek employment at the forest, gold and cocoa farms at Southern Ghana. Hence, rural-urban migration would be pleasingly reduced. Salaries and benefits due these workers would certainly be used to reinvest and expand farmlands, trade and businesses back at home. Such investment and business expansion accruing from income earned from airport direct and indirect employment of local labour force, in turn create avenues for new employment and job opportunities for family members, friends, peers and other relations.

Moreover, the airport stands to attract capital and enterprises to exploit the expanding demands for locally produced goods and services. Thus, increases local pool of trained industry's labour supply. It is a great asset for educational development and illiteracy eradication, bridging the socio-economic gap between the north and the south of Ghana. For example, although the first explicit advertising of Bali as a tourist destination took place in 1914, visitations remained small until 1969, when the international airport was opened. The development of the airport followed the opening of the first large coastal hotel (The Bali Beach Hotel) at Sanur in 1966. Villages grow agricultural products to feed tourists, perform for tourists in hotels and restaurants. 
With the proximity of the Tamale airport to all parts of the northern sector of Ghana, ancillary industries that supply input to the air transport services shall consider locating nearer to source of raw materials or cheap labour, because, transport cost would no longer be a deterring factor. For example, printers who print: timetables, menus, flyers, and brochures, tailors who make uniforms for airlines, car rentals would find drivers, as well as administrative secretaries who work for companies that provide outside services to airlines. Ultimately, series of expansions shall cast their shadows in general wealth creation. Through taxing of individual earnings, induced investments, and corporate dividends, local government funds shall be expanded. This could inadvertently create new jobs and wealth, for the youth in particular through provision of better infrastructure and industrial development. An estimated every million passengers, at least 1000 airport jobs are generated and 200 off-airport jobs (modern Ghana.com). On top of all these, the presence of efficient air transport system in the north can halt the apparent disparity and ostensible marginalization of the regions and foster national unity. The map below illustrates the linkage. The black arrows represent central places, whereas the red arrows represent zones of influence. Tamale is the highest central place in order of importance (market and transport). The arrows generally indicate the effects of the airport mentioned earlier.

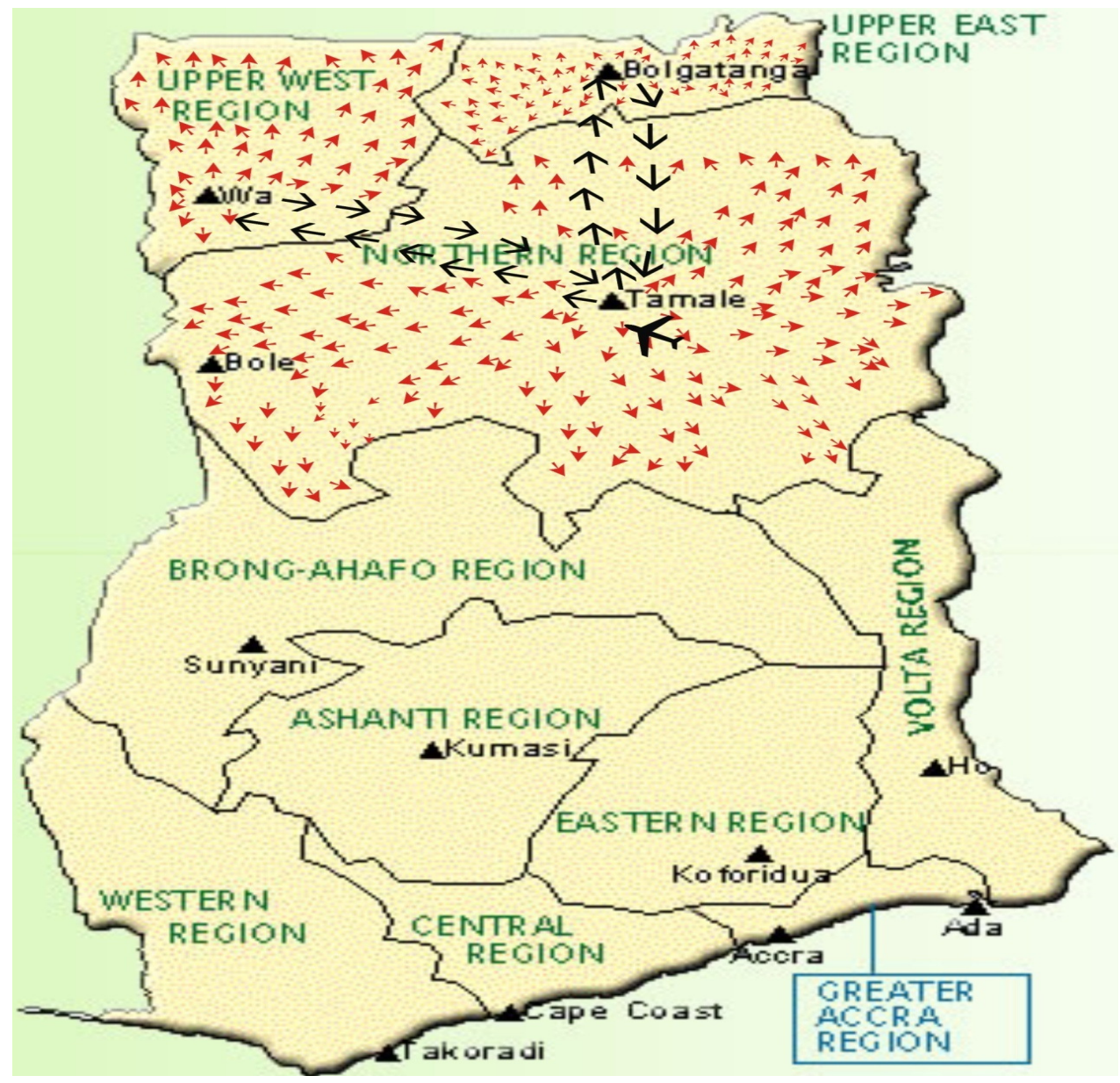




\section{Tamale Airport in Perspective}

Aviation is the second largest transport sector after road traffic. To transport high value goods and fresh agricultural products to meet the requirements of the international market, Ghana needs air transport, which is a more reliable and faster mode of transportation.

The Tamale Airport is one with bright future prospects due to its location $(13 \mathrm{~km}$ NorthWest of Tamale), its improved set of visual navigational aids, and its runway length of $2435 \mathrm{~m}$. Preliminary technological drawings towards upgrading the airport to an international status are complete, awaiting finances and government's commitment.

On 12 January, 1929, the second Airplane landed in Ghana. This time, the destination was Tamale. The airplane was a Tiger Moth with cirvous engine and registration number GE-BZZ. The airplane was piloted by Captain R.S. Rattray, a provincial commissioner in the gold-coast. The flight route into the country was via Ouagadougou (administrative capital of Burkina Faso) to Tamale. 240 miles were covered in 3 hours 30 minutes. Tamale to Accra by air is 280 miles, which was covered in 4 hours 40 minutes.

Tamale Airport was founded as a main advanced operational base for troops during the Second World War. The landing strip was acquired at Nyohene (a suburb of Tamale), some two miles west of Tamale, in December, 1940. In 1942, the royal Air Force Headquarters, West Africa, issued an instruction for work on the Tamale Airport runway to be completed as planned. The Nyohene -Tamale Airport was completed before 1948. The airport infrastructure included a control tower, Crash Rescue and Fire Service, Air traffic control offices, standing generator services, public place of convenience and seven junior staff offices.

Realizing the strategic position of Tamale, the first republican government of Ghana lead by Dr. Kwame Nkrumah approved the plan to build a new International Airport, 11 miles North-West of Tamale. The president had reserved hopes of using Tamale Airport as the headquarters of a multinational African High Command. Unfortunately, the overthrow of Nkrumah in 1966 brought this project to a halt.

Ghana Air Force has being operating from the Tamale new Airport since 1974. The design of the airport included a complex underground bunker for military aircraft. Initially, it was used as a detachment base. Construction resumed on the proposed International Airport during National Redemption Council (NRC) regime, lead by colonel Acheampong. The designs and plans were modified to accommodate civil operations.

Following the closure of the old airport, a beacon and other radio equipment were transferred to the new airport. The beacon broke down later in 1974. The Air Force did not have expertise to repair the beacon. Consequently, the NRC government instructed the Civil Aviation Department (CAD), with the men and expertise, to take over operations of the airport (Dwemoh and Associates, 2007 p.23).

\section{Table 1: Features of the proposed Tamale International Airport}

City

Location

Elevation

Runway Directions

Runway Length

Runway Width

Runway Surface

Lighting

Marking

Parking Ramp

\section{Tamale}

$09^{\circ} 34^{\prime} 00^{\prime \prime} \mathrm{N} ; 00^{\circ} 52^{\prime} \mathrm{W}$

$552 \mathrm{ft}(168 \mathrm{~m})$

$05 / 203$

$8000 \mathrm{ft}(2438 \mathrm{~m})$

$150 f t(45 \mathrm{~m})$

Asphalt 0.5-1.5 inches thick

Not working, but all features in place for edges and taxi way, apron light, and to bar visas.

Installed but barely visible

Adequate in size for four model 737 Aircraft: Surface in good condition 
An estimated amount of US $\$ 118,373,456.10$ is required to upgrade Tamale Airport for international operations. The scope of works is as follows:
a) Rehabilitation of existing runway and taxiway
b) Extension of existing runway length to a total of 4,000 meters
c) Construction of Runway End Safety Area at both ends of the runway
d) Improvement of site drainage
e) Provision of airfield pavement markings
f) Grading of Runway Strip
g) Extension of Perimeter/Fence
h) Construction of Perimeter Fence Road
i) Provision of utility/ Dry ducts across runway extension
j) Provision and installation of AGL
k) Installation of Fuel Mains facilities

Currently 3 of 4 domestic airlines are destined for the new Tamale airport on daily basis (Table 2).

Table 2: Airlines destined for Tamale Airport

\begin{tabular}{lll}
\hline Airline & Schedule & Route \\
\hline Antrak Air & Arrival; 7:00am, Departure; 7:30am & Accra-Tamale-Accra \\
Star bow & Arrival; 8:00am, Departure; 8:45am & Accra-Tamale-Accra \\
Fly540 & Arrival; 1:00noon,Departure; 1:40pm & Accra-Tamale-Accra \\
\hline
\end{tabular}

However, the schedules and fixtures are subject to change depending on weather conditions. The Tamale proposed International Airport currently hosts a working population of approximately 100 personnel, directly employed by GCAA, GACL, Airlines and other industries at the airport premises. In 2009, pilgrims from the three northern regions flew from and returned to the Tamale Airport by transit through KIA, contributing to a successful pilgrimage year ever in the history of Ghana. In effect it is a great national asset to reckon with, and deserves the necessary attention to air-lift pilgrims and many others direct to their destinations. Flight distance from Tamale to Accra has been reduced from 4 hours 40 minutes to just an hour.

\section{Conclusion}

Air transport is one of the world's most important industries. Its development, technical and service achievements make it one of the greatest contributors to the advancement of modern society. Since the first jet airline flew in 1949, use of commercial aviation has grown more than seventy folds. This growth is unmatched by other forms of transportation, and is essential to economic progress.

A finding of this study is that air transport contributes to sustainable development by facilitating tourism and trade. This generates economic growth; provides jobs, increases revenues from taxes and fosters the conservation of protected areas as a means of poverty alleviation.

This paper also finds that air transport makes substantial direct contribution to developing and transition economies. For example, according to OEF report, 2004, air transport supports about 170,000 jobs in Africa. 
This paper finds that many industries use air transport to shorten delivery times as part of their just-in- time delivery systems. This enables them to deliver products to clients quickly and reliably to reduce cost. News paper publishers and express mail service companies such as EMS, DHL and FEDEX are typical beneficiaries of such services in Ghana at present. The aviation sector has also contributed to trade in same day and next day delivery services and to the transportation of urgent or time sensitive goods such as fresh fruits, vegetables and flowers; benefiting many developing countries. Businesses report that passenger air services are at the least sometimes important for their sales, considering them to be vital. This dependency on air services means that companies have incentives to locate their operations in the vicinity of major airports.

Moreover, this study unearths that the air transport sector creates direct employment in areas such as passenger carriers, air cargo carriers, airline ticketing, and general aviation activities. The industry also creates employment through its supply chain including offsite fuel suppliers, food and beverage vendors, and construction firms. The industry's most important contribution is its impact on the performance of other industries and as a facilitator of their growth. Examples are ability to serve larger markets, business operations, influences on investments and labour market, as well as leisure travel stimulation.

In lieu of the foregoing, the study wishes to mention that with great ambition, African countries have embraced the virtues of the air transport industry at a multi-lateral level to facilitate intra African movement of goods and people so as to reshape these ostensibly dim realities in the individual countries

Ghana's World Bank-Sponsored trade and investment gateway project aims to attract export oriented investors and to place the country as a hub in West Africa. This shall enhance trade and passenger flows through measures such as absolute deregulation of the air transport industry and investment.

The productive capacities of all regions are mobilized by linking them in both structural and organizational sense to the mainstream of national economy. The need to reduce inequality and adverse polarization, thereby ensuring greater national progress through collective use of the resources of all areas in the country provides the basis for air transport development in the most deprived regions of Ghana.

To achieve regional development requires taking deliberate measures that will ensure effective and efficient allocation of national resources in such a way as to achieve relative equity among all regions and social groupings. The location programming of investments within a sector, such as air transport, for plans to promote industrial development away from the national capital, seeks to co-ordinate the establishment of roads, market centres, enclaves and credit facilities for low income regions.

This study empirically measures economic effect of air transport in Ghana, keeping the north in focus. Passengers demands are used to verify the theoretical structure which predicts the internationalization of the Tamale airport, thus, result in improved services quality. It is suggested, therefore, that more benefits can be unlocked in the form of the combined impact of aviation operations, airport investments and other industries. Strategic actions taken in the next few years will be critical to the vitality of the air transport industry in Ghana, if the industry is to continue to play its historical roles as one of the fundamental pillars of economic growth in the world.

The magnitude and strategic ramification of the air transport sector on the regional and by extension, the national economy and social quality of life, signals that government 
intervention is likely to occur. "....that international air transport services may be established on the basis of equality of opportunity and operated soundly and economically...." (ICAO, 2009).

This study desires so much to invite the concerted efforts of the Savannah Accelerated Development Authority (SADA), GCAA, GACL, and Government to the urgent development of the proposed Tamale International Airport. SADA is a statutory body established by an act of parliament with the sole objective of harnessing resources for the total development of Northern, Upper West, Upper East, and the northern most parts of Brong-Ahafo and Volta regions of Ghana. Being connected to the rest of the world has become increasingly important for business vitality, especially in an age in which global information quickly determines investment, production and consumption decisions. Regions and local businesses that are readily accessible from anywhere on the globe stand to benefit from the international movement of resources.

\section{References}

Airport Council International Europe (2004). The Social and Economic Impact of Airports in Europe. Brussels.

Dwemoh, E.R.K. and Associates (2007). History of Civil Aviation in Ghana, Ghana Civil Aviation Authority.

Hilhorst, J.G.M. (1967). Regional Planning: A systems Approach. Rotterdam University Press.

International Civil Aviation Organization (ICAO, 2004).Economic contribution of Civil Aviation.

International Civil Aviation Organization (2004). Economic Contribution for Civil Aviation.

OEF (2002). Tourism Satellite Accounts.

OEF (2005). Measuring Airline Network Benefits. Survey Conducted on behalf of International Air Transport Association (IATA).

OEF (2007). Aviation Services for the city of London. Survey carried out in the central London Business District.

Office of Policy and Planning (2005). The Economic Impact of the Aviation Industry on the New York -New Jersey Metropolitan Region. A study conducted for the Aviation Department, New York-New Jersey Metropolitan Regions.

Oxford Economic Forecast (OEF, 2004):Regional Employment and GDP impact

Oxford Economic Forecast (March, 2005.The Impact of the Express Delivery Industry on the Global Economy.

Oxford Economic Forecasting (OEF) (2005). The Economic and Social Benefits of Air transport. A study under taken for Air transport Action Group (ATAG)

Oxford Economics (2010). The Economic Impact of Air Travel Restrictions.

World Travel and Tourism Council (WTTC) (2005). Tourism Satellite Accounts.

Yaro, J. A. (2009). Theory and Practice of Geography, Geog 305. Institute for Continuing and Distance Education (ICDE) model, University of Ghana. 